Hydrology and Earth System Sciences, 8(3), 279-285 (2004) C EGU

\title{
An overview of forest management and change with respect to environmental protection in the UK
}

\author{
R.A. Farmer ${ }^{1}$ and T.R. Nisbet ${ }^{2}$ \\ ${ }^{1}$ Forestry Commission Wales, Victoria Terrace, Aberystwyth, Ceredigion SY23 2DQ \\ ${ }^{2}$ Forest Research, Environmental Research Branch, Alice Holt Lodge, Farnham, Surrey GU10 4LH \\ Email for corresponding author: tom.nisbet@forestry.gsi.gov.uk
}

\begin{abstract}
This paper overviews changes in forest management in the UK with respect to environmental protection. The evolution of policy is explained from historical and sustainability perspectives and covers developments in forest planning, accreditation, devolution and future challenges and opportunities.
\end{abstract}

Keywords: forest management, best practice, sustainable forestry, environmental protection, land use change

\section{Introduction}

Over the last century in the UK, there has been a major expansion in plantation forestry in response to the national need for timber. Through that time, the nature of forestry and the goals of forest management have evolved. The impacts of forestry on the environment have also been investigated and environmental research has played an important role in quantifying the effects and influencing developments in forest policy and practice. Today, the emphasis is on achieving forestry that is sustainable and makes a positive contribution to the environment. This paper describes the key stages in this process of change.

\section{Historical perspective}

Much of today's British forest landscape has its origins in the policies developed after the First World War during which extreme demands were made on indigenous forests to meet the war needs, especially pit props to sustain coal production. The forests of Britain were devastated; only those in remote locations, or where timber extraction was very difficult, escaped these ravages.

The Government formed the Forestry Commission in 1919 to reinstate and expand Britain's forests, to ensure that the nation would have a strategic resource of timber to meet the needs of a future war. This led to a simple forest policy of bringing as much land as possible into productive forestry and maximising timber yields by the dense planting of fastgrowing conifers, originating mainly from North America. The Forestry Commission acquired land for new State forests and developed and administered a variety of schemes to help promote planting by private landowners. Much of the planting was on former upland sheep farms, reflecting the dire state of farming and the low land prices at the time. In this respect, forest expansion had a vital secondary role of providing desperately needed employment at a time when other traditional rural industries were in crisis.

The strategic timber objective was further reinforced by the experiences of the Second World War when the meagre home timber reserves were again depleted. Policy was reaffirmed and led to an acceleration of conifer planting in the late 1940s and 1950s. Despite the emergence of nuclear weaponry and the reduced likelihood of a long-lasting conventional war with its attendant demands for timber, annual planting rates peaked increased to $>40000 \mathrm{ha} \mathrm{yr}^{-1}$ in the early 1970s (Forestry Commission, 2002a). Viewed within the narrow terms of establishing a strategic reserve, the policy was extraordinarily successful; more than 2 million hectares of timber forest were established by the 1980s, half on Forestry Commission land, half in private 
ownership. This doubled the forest cover in the UK from about $5 \%$ to $10 \%$.

As conifer afforestation transformed the upland landscape during the 1970s and $80 \mathrm{~s}$, the hidden environmental costs began to emerge. The impacts of the rapid expansion of upland conifer afforestation on water and landscape were the first issues to come to the fore. Initially the effects on quantity and stream flow dominated the debate. Accumulating evidence of the greater water use of forests compared to moorland led to concern that afforestation would reduce water supplies significantly and dry up streams (Calder and Newson, 1979). At the same time, pre-planting ploughing and drainage practices increased peak flows (Robinson, 1986). These issues subsided with the decline in heavy industry and the associated decline in water demand during the 1970s, but were replaced by increasing fears over the potential of forestry to degrade water quality (Maitland et al., 1990).

A major water quality issue was the potential for forest cultivation, drainage and road building operations to cause serious soil erosion and sedimentation. In a number of high profile cases, forestry polluted rural water supplies severely or caused localised heavy siltation of fish spawning gravels (Richards, 1985; Stretton, 1984). The Forestry Commission improved management practices on its own estates, and published guidance to influence the private sector. Early developments included the improved design of drainage systems to reduce the risk of erosion (Thompson, 1979) and a greater emphasis on streamside management following the recommendations of Mills (1980). A central element of stream side management involved leaving an uncultivated and unplanted buffer area of land alongside streams to ensure a cover of ground vegetation to stabilise soil and to act as a filter for sediment.

The rise in environmental awareness during the 1980s and arrival of new issues such as acid rain, brought industry experts together in 1986 in an effort to find improved ways of controlling the threat of diffuse pollution from forestry. A joint working group was formed and led to the publication by the Forestry Commission of a comprehensive set of best practice guidelines in 1988 (Forestry Commission, 1988). The Forests \& Water Guidelines essentially advises forest managers on working methods and on those measures that should be taken to ensure that water draining from forests remains of a satisfactory standard. Compliance with the Guidelines is a condition of Forestry Commission approval of forestry operations on public lands, and for the issuing of grants for the establishment and management of forests on private lands.

Other environmental concerns centred on landscape and the lack of diversity in tree species, planting density and age structure, with many of the forests comprising extensive monocultures of even-aged Sitka spruce. Planting seldom took account of nature conservation interests and increasingly threatened open bog and heathland habitats. From a landscaping perspective, these forests were viewed as clothing hillsides in an endless dark 'blanket', often forming geometric shapes that 'jarred' with the natural landform. This lack of diversity was perpetuated into the second rotation as areas were felled purely on economic maturity criteria, meaning that large tracts were cleared in short periods, commonly referred to as 'rolling back the carpet'. The Forestry Commission addressed these issues by extending their suite of environmental guidelines to include Forest Nature Conservation (Forestry Commission, 1990), Community Woodland Design (Forestry Commission, 1991), Lowland Landscape Design (Forestry Commission, 1992a), Forest Recreation (Forestry Commission, 1992b), and Forest Landscape Design (Forestry Commission, 1994),

\section{Sustainable forestry}

The early 1990s saw a marked change in Government forest policy involving a shift away from timber production to the wider benefits associated with multi-purpose forestry. This was partly driven by international developments, including Government commitments made at the 1992 United Nations Conference on Environment and Development in Rio de Janeiro, and at the 1993 Ministerial Conference on the Protection of European Forests in Helsinki. Sustainable forestry became the watchword and in terms of the physical environment, reinforced the need to protect both forest soils and water. A major milestone was the publication of the UK Forestry Standard in 1998, which sets out the criteria and standards for the sustainable management of all forests and woodlands in the UK (Forestry Commission, 1998a). The standard draws on the specific recommendations listed in the Forestry Commission's range of environmental guidelines, notable additions to which included Forests and Archaeology (Forestry Commission, 1995) and Forests and Soil Conservation (Forestry Commission, 1998b).

\section{Forest design planning}

Another important development in the early 1990s was the introduction of the forest design planning process, initially limited to State forests but then extended into the private sector. This provided an integrated approach to solving landscape, recreation, conservation and water issues at the scale of the forest as a whole. Forest design planning aims to create a permanent forest structure that reflects all 


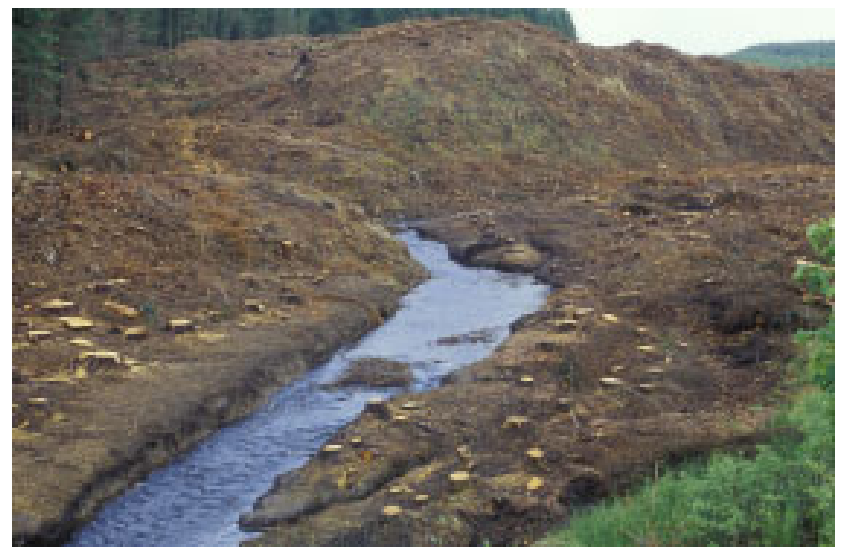

Fig. 1. The removal of dense shade from streamsides is helping to improve the freshwater environment within upland forests.

environmental and other sensitivities. This includes the need for a significant proportion of open land for other habitats such as upland heath, as well as to enhance heritage and recreation. Crucially, the plans are subject to meaningful consultation with a wide range of stakeholders, ensuring an equitable balance is achieved among all interest groups. The productive forest often remains at the core of the structure but in such a way that planned fellings are of an appropriate scale and related to landform, and replanting ensures an increasing diversity in tree species and age. Another key element is the re-design of streamsides to form a native riparian woodland habitat network and wildlife corridor stretching throughout the whole water catchment. First rotation stands that cast dense shade over the water's surface are progressively being cleared back from streams, to be replaced in time by an open canopy of mainly native broadleaved woodland (Fig. 1). This is transforming the freshwater environment within conifer plantations.

An example from Wales of the process of Forest Design Planning, as it has evolved over the last decade, is shown in Fig. 2. Pennal Forest is located in the south of the Snowdonia National Park and extends over an area of approximately 1000 ha at an altitude of $100 \mathrm{~m}$ to $475 \mathrm{~m}$. The first "whole forest design" was produced in 1994 (Fig. 2 top) and, in its day, was considered to be ground-breaking. It sought to establish an extensive riparian zone 'built' around relic areas of native woodland, including oak, ash, alder, small-leaved lime, birch and willow. The zone accounted for some $10 \%$ of the forest, which had previously been dominated by dense conifer stands. The second generation Forest Design, completed in 2000 (Fig. 2 bottom panel) now includes an expanded riparian zone, a large increase in adjacent broadleaved planting and a substantial additional area of larch, which being deciduous and managed at a lower stand
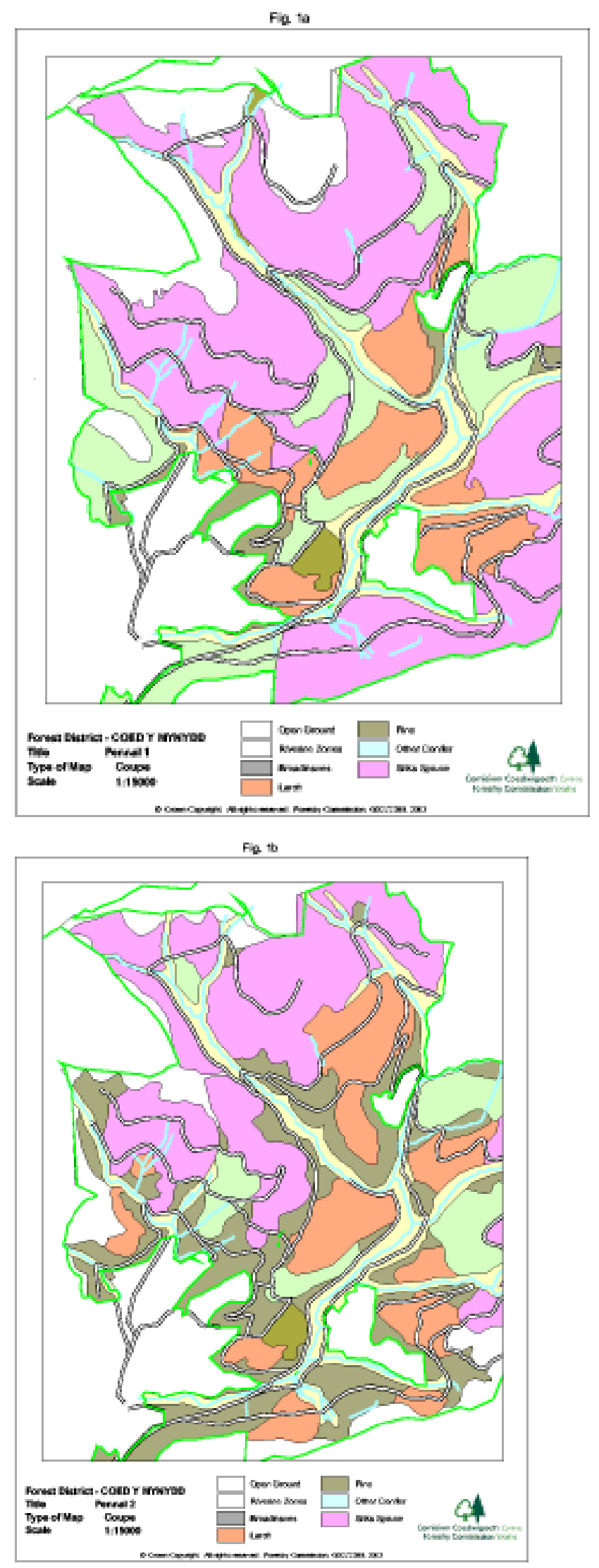

Fig. 2. Comparison of Forest Design Plan for Pennal Forest in the Snowdonia National Park between 1994 (top) and 2000 (below). 
density, will be conducive to further natural regeneration of broadleaves. As the plans depicted in Fig. 2 come into effect over the next two decades, the freshwater environment and associated wildlife habitats should be greatly enhanced. The resulting landscape of enriched valleys and riversides is expected to attract more walkers, anglers and bikers, increasing support for local tourism and rural development. The forest will nonetheless continue, though less obtrusively, to produce much conifer timber for the forest industry.

\section{Forestry expansion}

During the 1990s, conifer planting declined markedly and has led to a shift to predominantly broadleaved native woodlands, farm woodlands and community woodlands. New broadleaf planting overtook that of conifer for the first time and the area of farm woodland almost doubled between 1981 and 2001 to a total of around 500000 ha. The growth in community woodlands was particularly significant, with new woodlands planned for the National Forest in the Midlands, Red Rose in Merseyside, Thames Chase near London, the Valleys Forests in Wales, and the Central Belt Woodlands in Scotland. These, in essence, are woodlands for people, designed with more native broadleaves and open space to be suitable for leisure. Some are on brownfield sites once home to coal mining and other industrial uses.

The 1987 indicative annual target for new planting in Britain of 33000 ha was changed in 1996 to a doubling of woodland cover in England and increasing that in Wales by $50 \%$ over the next 50 years. This led to renewed concern about the environmental impact of such a large expansion of woodland. In response, the target was modified to one of achieving a steady expansion of tree cover. To tackle environmental concerns, Indicative Forestry Strategies and Local Forestry Frameworks were introduced in some parts of the country to highlight environmental sensitivities and help direct new woodland planting to 'preferred' areas. Other important checks on new planting included a strengthening of the Forestry Commission's consultation arrangements with local authorities and statutory bodies, as well as the formal process of environmental impact assessment. A public register of new planting and felling applications was also put in place to inform the public about forestry developments and provide an opportunity for comment.

\section{UK Woodland Assurance Scheme}

The voluntary UK Woodland Assurance Scheme (UKWAS), introduced in 1999, gave woodland owners independent assurance that their woodland management satisfied internationally recognised standards of sustainable management. The UKWAS incorporates the requirements of the UK Forestry Standard but is more detailed in addressing specific aspects of forest management or types of operation. Forestry Commission woodlands achieved certification in 1999 and have sustained this standard in subsequent annual independent audits. Many private woodlands have similarly fulfilled UKWAS requirements. Both the UKWAS and the UK Forestry Standard are continuing to drive improvements in practice, such as minimising the use of chemicals.

\section{Devolution}

The advent of devolved government in the late 1990s led each country to develop over-arching country strategies in relation to devolved functions. These form distinctive country 'backdrops' against which tailored country forestry policies and Woodland Strategies are emerging. In England, stress is being placed on community woods for recreation near the great conurbations, recognising the health benefits that woodland recreation can provide. In Scotland the focus is on the role of forestry in rural development, whilst in Wales priority is being given to the very specific role forestry can play in support of Wales' relatively more important tourism. All of the national strategies aim to integrate forestry with other countryside management to enhance the environment and achieve sustainable land use. By 2005, this process will be aided in England by the introduction of Regional Forestry Frameworks.

\section{Future directions}

Over the last decade prices of timber have fallen dramatically and perhaps for the long term. Causative factors include the dramatic shift towards recycling of paper and wood for products such as newsprint and particleboard, and the opening up of enormous wood supplies from the former USSR. As a result, some British forest crops are no longer economic to harvest and replant in the customary, resource intensive, way. This is accelerating the drive to redesign, manage and plant forests for multiple objectives, with a greater focus on providing environmental, social and community benefits.

There seems certain to be an increased role for Continuous Cover Forestry (CCF), where the forest canopy is maintained at one or more levels without clearfelling (Fig. 3). One of the drivers for this is 'economic', since significant cost savings can be made by exploiting the potential for crops to regenerate naturally rather than through active restocking. However, this requires a better understanding of silvicultural techniques to promote tree flowering, seed production, seed 


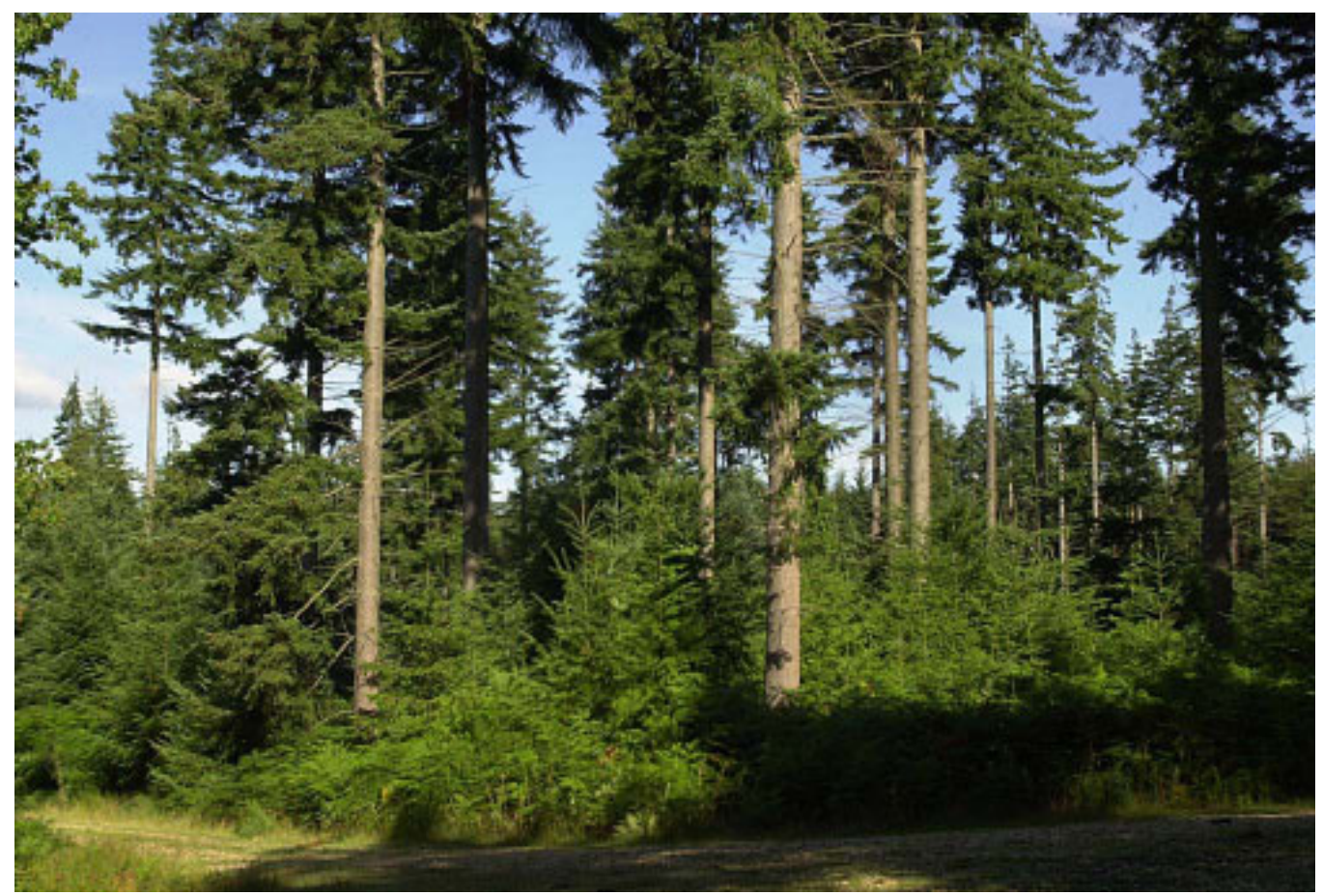

Fig. 3. A site undergoing transformation to continuous cover forestry.

germination and subsequent seedling survival (Mason et al., 1999). The development of appropriate thinning regimes has the potential to make CCF an option on a substantial part of the British forest estate, although large parts of the uplands are likely to remain unsuitable due to site exposure and the high risk of windblow. The Welsh Assembly Government has directed that $50 \%$ of the publicly owned Welsh woodlands should be brought into a CCF regime by 2020 .

A switch to CCF can provide a number of environmental benefits, not least in terms of reducing the visual impact of large clearfells. There is likely to be less soil and water disturbance, although the impact of maintaining a continuous tree cover, in terms of pollutant scavenging and water use, will need to be considered.

Ancient woodlands are increasingly being recognised as a special resource. On Forestry Commission Ancient Woodland sites, surveys of plantations have now been completed to assess their condition and priority for restoration to 'semi-natural woodland'. Major restoration programmes will follow if governments can find the necessary funding.

The ongoing reform of the Common Agricultural Policy has implications for the availability of land for new woodlands, though it is too early to determine what the specific effects will be. Opportunities are likely to arise for using woodland in a more proactive way to achieve environmental improvements, such as assisting the control of diffuse pollution and possibly even flooding. The European Union Water Framework Directive (2000/60/EC), which was introduced in 2000, requires Member States to reach good ecological and chemical quality status of surface waters by 2015 . Woodland could have an important role to play in helping to meet this objective due to its ability to protect soils, reduce rapid surface run-off and intercept pollutants. For example, woodland could be used in an agricultural landscape to help stabilise erosion prone soils, or within riparian buffers to retain sediment and chemical pollutants in run-off, and to protect stream banksides. The associated development of River Basin Management Plans will require action to integrate and improve land use planning and management at the catchment scale.

Best practice guidelines will continue to be reviewed regularly to ensure that they reflect the most recent research and experience (Fig. 4). The new (Fourth) Edition of the Forests and Water Guidelines (Forestry Commission, 2003) addresses the new pressures and opportunities that are likely to face forestry in the UK. Another significant development was the introduction of a comprehensive set of UK indicators of sustainable forestry at the end of 2002 (Forestry Commission, 2002b). These cover environmental, social and economic aspects of sustainable development and through monitoring, will provide a measure of the effectiveness of forestry policy and management practices. The Forestry Commission also adopted the concept of 'Integrated Pest Management' (IPM) in 2002, which tries to avoid pest 


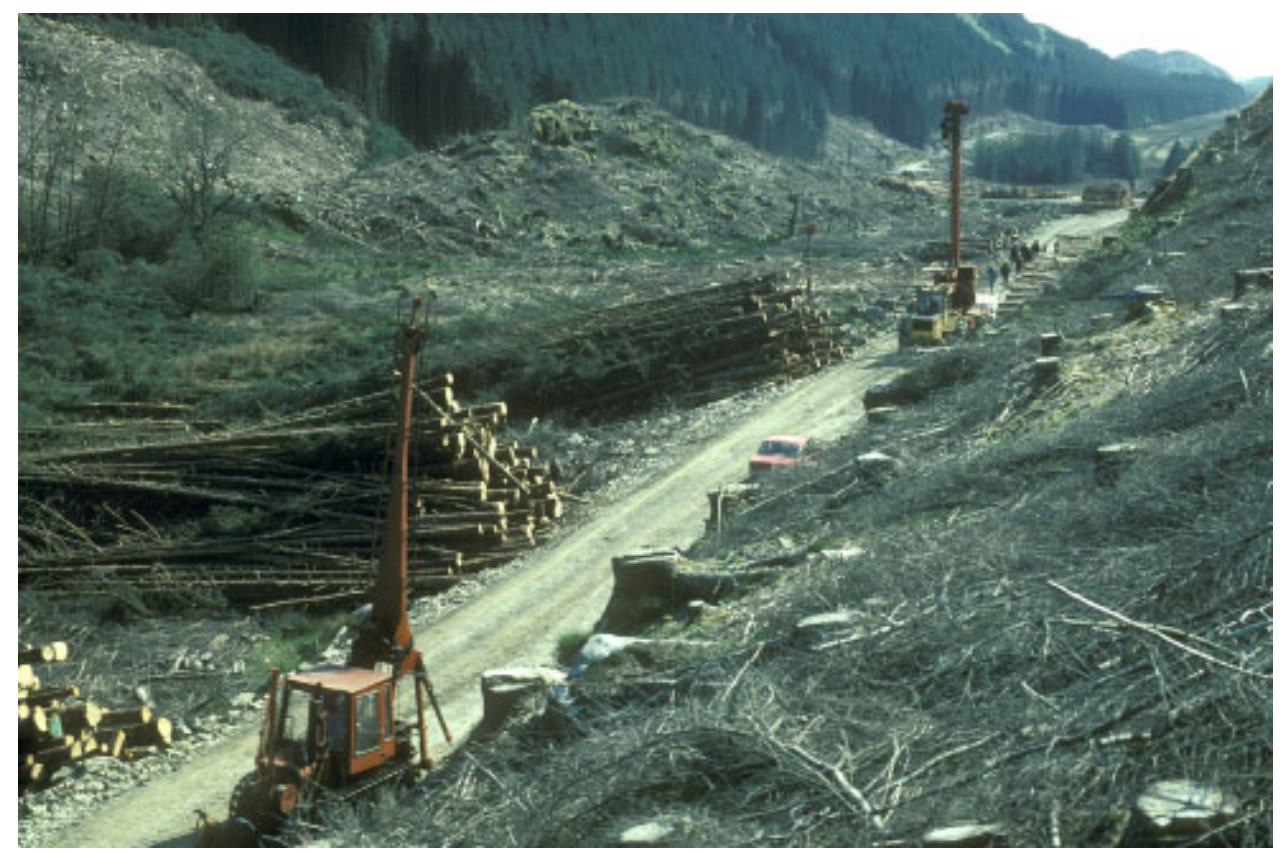

Fig. 4. Research has demonstrated the effectiveness of best practice in minimising the impact of clearfelling operations on the freshwater environment.

problems through preventative measures and biological control wherever possible. A new Forestry Commission Practice Guide 'Reducing Pesticide Use in Forestry' was published in 2004.

One new growth area could be the planting of short rotation coppice and the harvesting of wood for biomass fuel. The Government's commitment to renewable energy and attendant price support mechanisms makes it likely that there will be an increasing market for wood fuel in the future, initially for 'co-firing' with coal. A large quantity of material is potentially available in the form of harvesting residues, small round wood, saw mill conversion products and coppice crops, which could make a significant contribution to power and heat generation (McKay, 2003). However, the harvesting of wood residues represents an additional drain on site nutrition and may need to be excluded from some site types.

Climate change poses a special challenge for forestry, both in terms of the role of forests in helping to offset the rise in $\mathrm{CO}_{2}$ and the vulnerability of forests to damage (Forestry Commission, 2002c). Although climate change is expected to increase forest productivity where soil moisture and nutrients are not limiting, the scale imbalance between the amounts of carbon sequestered by forests and annual carbon emissions means that, in the long term, forestry is likely to remain a relatively small carbon sink. However, woodland expansion and good forest management could make an important contribution to limiting the rise in carbon emissions in the short-term, especially if accompanied by an increased use of wood and woody residues in fossil fuel substitution and as a construction material. This would provide much needed time for the implementation of low carbon technologies and the development of other potential solutions.

The benefits of forests for locking up carbon will be realised only if they are themselves protected from the effects of climate change. Potential major threats include the risk of increased damage by fungal disease and insect pests due to warmer winters, increased wind-blow as a result of more frequent and severe storms, and a greater risk of forest fires due to drier summers. Protection against these will require silvicultural adaptations, including species substitution and the strengthening of protection and control measures. Species change is also likely to be driven by climate warming. For example, beech woodland in south-east England is predicted to decline as a result of its sensitivity to drought. Climate change also presents problems for the water environment, including an increased risk of winter flooding and summer drought. Forest management will increasingly need to take account of the interactions with forestry, with the potential for both positive and negative impacts. On the positive side, the planting and restoration of riparian and floodplain woodland could aid flood control and help to reduce excessive summer water temperatures, while on the debit side there may need to be restrictions on the type and scale of future planting in some areas to protect water resources. 


\section{Conclusions}

The last century has seen major change in British forestry with significant implications for environmental protection. The programme of large-scale upland conifer afforestation in the period 1940-90 led to the introduction of a suite of environmental guidelines, starting with those covering forests and water in 1988. This was rapidly followed by a new policy of sustainable forestry, the introduction of the UK Forestry Standard, and a marked shift in emphasis from timber production to the many other diverse benefits that forests can provide. A wide range of pressures, including falling timber prices, agricultural reform and global warming, will continue to drive change, but protection of the environment will remain at the core of multi-purpose forestry. Evidence suggests that the advances in best practice that have taken place over the last $10-15$ years provide a sound basis for the sustainable management of the forest environment by forest planners and managers.

\section{References}

Calder, I.R. and Newson, M.D., 1979. Land use and upland water resources - a strategic look. Water Resour. Bull., 16, 1628-1639.

Forestry Commission, 1988. The Forests \& Water Guidelines. HMSO, London, UK.

Forestry Commission, 1990. Forest Nature Conservation Guidelines. Forestry Commission, Edinburgh, UK.

Forestry Commission, 1991. Community Woodland Design Guidelines. Forestry Commission, Edinburgh, UK.

Forestry Commission, 1992a. Lowland Landscape Design Guidelines. Forestry Commission, Edinburgh, UK.
Forestry Commission, 1992b. Forest Recreation Guidelines. Forestry Commission, Edinburgh, UK.

Forestry Commission, 1994. Forest Landscape Design Guidelines, Second Edition. Forestry Commission, Edinburgh, UK.

Forestry Commission, 1995. Forests and Archaeology Guidelines. Forestry Commission, Edinburgh, UK.

Forestry Commission, 1998a. The UK Forestry Standard. Forestry Commission, Edinburgh, UK.

Forestry Commission, 1998b. Forests and Soil Conservation Guidelines. Forestry Commission, Edinburgh, UK.

Forestry Commission, 2002a. Forestry Statistics 2002. Forestry Commission, Edinburgh, UK.

Forestry Commission, 2002b. UK Indicators of Sustainable Forestry. Forestry Commission, Edinburgh. UK.

Forestry Commission, 2002c. Climate Change: Impacts on UK Forests. Forestry Commission Bulletin 125. Forestry Commission, Edinburgh, UK.

Forestry Commission, 2003. The Forests \& Water Guidelines, Fourth Edition. Forestry Commission, Edinburgh, UK.

Forestry Commission, 2004. Reducing Pesticide Use in Forestry. Forestry Commission, Edinburgh, UK.

McKay, H., 2003. Woodfuel Resource in Britain. Forestry Commission Report. Forestry Commission, Edinburgh, UK.

Maitland, P.S., Newson, M.D. and Best, G.A., 1990. The impact of afforestation and forestry practice on freshwater habitats. Nature Conservancy Council, Focus on Nature Conservation, No. 23.

Mason, B., Kerr, G. and Simpson, J., 1999. What is Continuous Cover Forestry? Forestry Commission Information Note, Forestry Commission, Edinburgh, UK.

Mills, D.H., 1980. The management of forest streams. Forestry Commission Leaflet 78. Forestry Commission, Edinburgh, UK.

Richards, W.J., 1985. Problems of water management and water quality arising from forestry activities. In: Weather, Woodlands and Water, D.J.L. Harding, J.K. and Fawell (Eds.), Institute of Biology, London. 67-85.

Robinson, M., 1986. Changes in catchment runoff following drainage and afforestation. J. Hydrol., 86, 71-84.

Stretton, C., 1984. Water supply and forests - a conflict of interests: Cray reservoir, a study. J. Inst. Water Engr. Sci., 38, 323-330.

Thompson, D.A., 1979. Forest Drainage Schemes. Forestry Commission Leaflet 72. HMSO, London, UK. 